\title{
Development Of Electrical Motor Control Learning Media As Learning Support For Electrical Power Installation Courses In The Department Of Electrical Engineering
}

\author{
Supari Muslim ${ }^{1}$, Tri Wrahatnolo ${ }^{2}$, , Sri Handayani ${ }^{3}$, Erina Rahmadyanti ${ }^{4}$, Nita Kusumawati ${ }^{5}$, Joko ${ }^{6}$ \\ ${ }^{1}$ Pendidikan Teknik Elektro,Universitas Negeri Surabaya, Indonesia \\ Email: supari@unesa.ac.id \\ ${ }^{2}$ Pendidikan Teknik Elektro,Universitas Negeri Surabaya, Indonesia \\ Email:wrahatnolo@yahoo.com \\ ${ }^{3}$ Pendidikan Tata Boga,Universitas Negeri Surabaya, Indonesia \\ Email:yani.endro@gmail.com \\ ${ }^{4}$ Pendidikan Teknik Bangunan,Universitas Negeri Surabaya, Indonesia \\ Email: erinarahmadyanti@unesa.ac.id \\ ${ }^{5}$ Kimia,Universitas Negeri Surabaya, Indonesia \\ Email: nitakusumawati99@gmail.com \\ ${ }^{6}$ Pendidikan Teknik Elektro,Universitas Negeri Surabaya, Indonesia \\ Email: Unesa_Joko@yahoo.com
}

\begin{abstract}
Learning media is everything that can channel the message of learning resources in a planned manner, to create a conducive learning environment, where the recipient can carry out the learning process effectively and efficiently. Vocational learning must be effective in meeting basic objectives to prepare vocational graduates to be ready to work. Thus, it is an assignment for lecturers whose function is to prepare vocational teacher candidates. The question that arises is "how should a learning media be developed", so that the learning process in the classroom can run effectively and efficiently, so that students get optimum learning outcomes. For this reason, it is necessary to do research with the title "Development of Electrical Motor Control (EMC) Learning Media as Learning Support for Electrical Power Installation Courses in the Department of Electrical Engineering, Surabaya State University". This study aims: (1) to develop Electrical Motor Control (EMC) Trainer; (2) to find out the feasibility level of the Trainer in a learning perspective; and (3) to determine the effectiveness of the EMC Trainer in the learning process. The research method uses Research \& Development $(R \& D)$, followed by experiments with the design of "one-group pretest-posttest design". The study found that: (1) based on the validator's assessment, that the EMC Trainer that had been developed was very feasible to be used in learning in the Electrical Power Installation course; (2) based on the assessment of students, that the EMC Trainer is very suitable to be used in learning courses in Electric Power Installation; and (3) as many as 26 (74.28\%) students get scores on learning outcomes in the 71-100 range, with good and excellent categories. The study concluded that the EMC Trainer is very feasible and effective to be used to support the learning of Electric Power Installation courses.
\end{abstract}

Keywords: Media; Electrical Motor Control; $R \& D$ 


\section{INTRODUCTION}

Education is a conscious and planned effort to create a learning atmosphere and learning process, so that students actively develop their potential to have religious spiritual strength, self-control, personality, intelligence, noble character, and skills needed by themselves, society, nation, and state (Law of the Republic of Indonesia Number 20 of 2003, Article 1, paragraph 1). Vocational High Schools (SMK), prioritizing the preparation of their students to be able to choose careers, enter employment, compete, develop themselves successfully in jobs that are rapidly changing and developing.

The objectives of the Vocational School will be achieved through the 2013 curriculum, which is developed based on internal and external challenges. In dealing with internal challenges, the 2013 curriculum was developed with reference to: (1) to eight National Education Standards which include content standards, process standards, graduate competency standards, educator standards and education personnel, standards of facilities and infrastructure, management standards, financing standards, and standards educational assessment; and (2) to an effort, so that abundant productive human resources (around 70\% of Indonesia's population) can be transformed into human resources that have competencies and skills through education, so as not to become a burden of future development. While the external challenges of the 2013 curriculum are: (1) related to various issues concerning environmental issues, advances in technology and information, and the rise of creative industries; and (2) a shift in the lifestyle of people from traditional agrarian and commercial properties, to modern industrial and trade communities as seen in the World Trade Organization (WTO), Association of Southeast Asian Nations (ASEAN) Community, AsiaPacific Economic Cooperation (APEC) and ASEAN Free Trade Area (AFTA).

For these reasons, vocational education (including vocational education) as an integral part of "Technical and Vocational Education and Training (TVET)" was chosen by UNESCO and ILO as a system of technical and vocational education and training for all humanity within the framework of "Education for All "(Sudira, a., 2018, p.1). Given the importance and strategic importance of vocational education (which is often also referred to as vocational education), Presidential Instruction (Inpres) No. 9 of 2016 has been issued, concerning the revitalization of vocational education. With Presidential Instruction No. 9 of 2016, vocational education is directed at "implementing a dual system" through learning theory in vocational schools and implementing practices in the business and industrial environment. Revitalization also involves changing the philosophy of vocational education, from "supply-driven" to "demanddriven".

This revitalization program also has an impact on the preparation of vocational school teachers, which have been carried out by the Educational Personnel Education Institution, including the Department of Electrical Engineering, Faculty of Engineering, Surabaya State University. With the revitalization program, the design of learning in Vocational Schools needs to be adapted to the competencies needed by business and industry, with the main focus on agriculture, maritime, tourism, and creative industries. Therefore, improving the quality of teachers and education personnel, as well as providing infrastructure (including learning media), is an important part of the vocational education revitalization program (Vocational Education Revitalization Manuscript, 2016). Learning media is everything that can channel messages as a planned source of learning, so as to create a conducive learning environment, where the recipients can carry out the learning process effectively and efficiently (Munadi, 2010, p.7). Vocational learning must be effective in meeting basic objectives in order to prepare vocational graduates to be ready to work (Sudira, -a, 2018, p.2).

Besides paying attention to the effectiveness factor, the aspect of school transition to the world of work, is an important aspect that needs to be considered in vocational learning in the XXI century (Sudira, -b, 2018, p. 56). Thus, it is an assignment for lecturers whose function is to prepare vocational teacher candidates. The question that arises is "how should a learning media be developed", so that the learning process in the classroom can run effectively and efficiently, so that students get optimum learning outcomes. For this reason, it 
is necessary to conduct research with the title "Development of Electrical Motor Control (EMC) Learning Media as a Learning Support for Electrical Power Installation Courses in the Department of Electrical Engineering, Surabaya State University".

This study aims to: (1) to develop an Electrical Motor Control (EMC) Trainer; (2) to find out the feasibility level of the Trainer in a learning perspective; and (3) to determine the effectiveness of the EMC Trainer in the learning process.

As explained above, that how a learning media must be developed ", so that the learning process in the classroom can run effectively and efficiently, so that students get optimum learning outcomes. Akhtar \& Ali (2012, p.35) see that media is a means to send messages in a learning perspective. While according to Preeti (2014, p. 174), that media comes from the word medium which means something designed, to reach many users, including students in learning. In line with that opinion, that educational media is a communication channel that carries messages with instructional objectives (Omadara \& Adu, 2014, p.50), which consists of 5 classifications namely: (1) print media; (2) non-printed media; (3) electronic media; (4) audio media, \& visual media; and (5) hardware and software media.

There are several results of research on learning media, which have been carried out by researchers, including the use of car learning as a learning medium. Sarrab et al. $(2014$, p.182) in his research entitled "From Traditional Learning into Mobile Learning in Education at the University Level: Undergraduate students' perspective", which found that: (1) mobile learning can mask the shortcomings of traditional learning; (2) mobile learning is not a substitute for traditional learning systems, but as a compliment; and (3) more than half of participating students showed interest in using cellular learning. A similar study was conducted by Vesselinnov \& Grego (2012, p.1) who found that: (1) there was an increase in language skills of $91.4 \%$; (2) there is an increase in measurement of effectiveness of 8.1 points per use of duolingo for one hour of research; (3) participants who have no prior knowledge of Spanish need an average of 34 hours per semester, to understand universities in Spain; and (4) novice participants recorded the highest increase, while non-beginner participants recorded the lowest increase.
Furthermore Teodorescu (2015, p. 1539-1540) in his research entitled "mobile learning and its impact on learning English" found that the use of mobile learning in learning English can provide benefits for: (1) listening directly to native speakers of English; (2) improve the ability to speak, and listen; (3) can be learned anywhere; and (4) increase students' confidence. The results of this study are supported by Preeti's findings (2014, p. 175), that by utilizing media, the learning process becomes more interesting, and more effective.

In connection with the results of the aforementioned research, Syarief and Isdianto (2015) conducted a study entitled "props for analyzing electromagnetic control disturbances on subjects operating electromagnetic control systems in class IX of SMK 3 Semarang" which found that there were significant differences between the results student learning in the experimental class and control class ( $\mathrm{t}$ count of 2.72 is greater than $t$ table of 2.00). A similar study was carried out by Wirawan and Wahyudi (2016) with the title "development of electromagnetic trainer displays as learning media for basic electric concepts" which concluded that in the control class there was an increase in learning outcomes scores from 56.69 to 72.3 , and in the experimental class an increase score of 56.11 to 77.44 .

Furthermore, Eliza, Myori, and Wireksi (2017) conducted a study entitled "electronic control system trainers in electronic control system learning" found that: (1) the validation performed on media trainers scored 0.91 with a very high category; and (2) the effectiveness test for trainers states that as many as $89.3 \%$ of students achieve minimum completeness criteria. Completing the two studies, Widiantama (2017) conducted a study entitled "the development of DC motor speed control system trainers as a medium for learning robotics practice concluded that: (1) the assessment of media experts on trainers, obtained a score of 72 with a feasible category; and (2) as many as $50 \%$ of students stated that trainers were worthy of being used in learning, and the remaining $50 \%$ of students stated that trainers were very feasible to use for learning.

Students in The three results of the above research are supported by the findings of Muslims, Achmad, Budi, and Aribowo (2018) in his research journal entitled "development of human mechanic interface auotonics S070 trainer for electric motor installation learning" 
which found that: (1) tests on media content by instructional media experts, obtained "very decent category" with a percentage of $89.58 \%$; and (2) with a learning media trial of 30

\section{METHOD}

This research is a research development ( $R$ $\&$ D), which is carried out using the ADDIE method (Brog \& Gall, 2003), with
Surabaya Navy 1 Special Vocational School, "very feasible category" was obtained with a percentage of $83.04 \%$. developmental steps as shown in Figure 1 below.

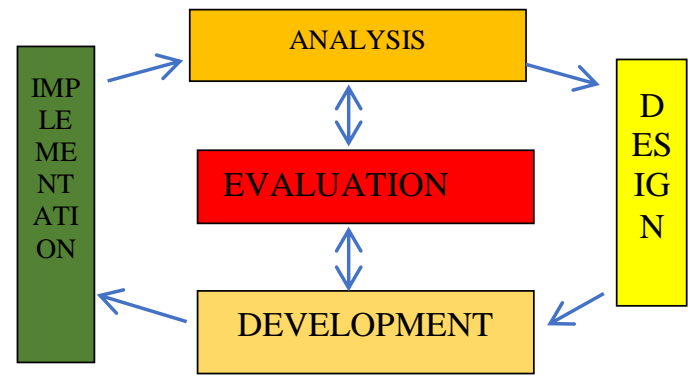

Figure 1. Research Steps Development (R \& D) ADDIE

(Source: Brog, W.R. \& Gall, M.D., 200)

Based on the steps of ADDIE development research (Brog, and Gall, 2003) as shown in Figure 1 above, the procedure for developing Electrical Motor Control Learning Media (EMC Trainer) in this study was carried out through the procedure as shown in Figure 2 below. The research consists of 4 steps, namely analysis, design, development, and implementation.

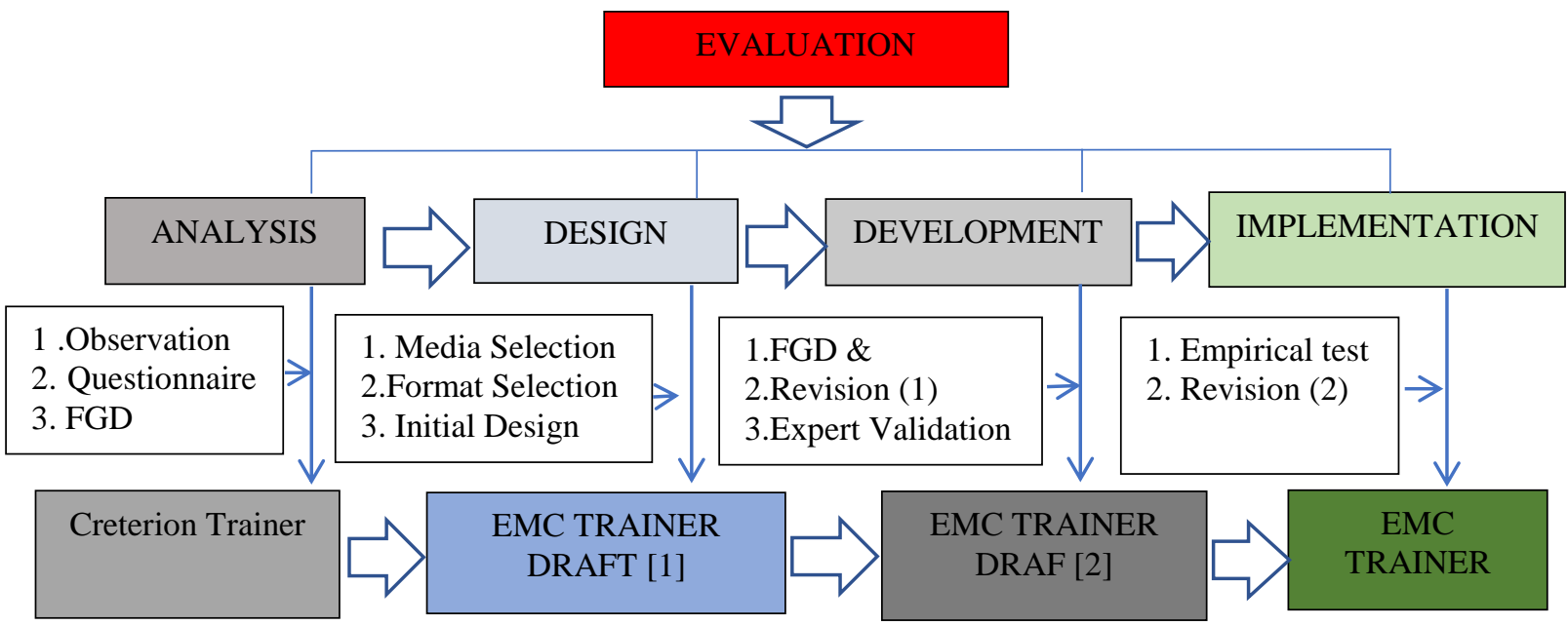

Figure 2. Development Procedure of EMC Trainer Adaptation from ADDIE (Source: Brog, W.R. \& Gall, M.D., 2003)

Research procedure: (1) Analysis: in the first step this was done by examining learning media conducted in the field through observation, questionnaires, and focus group discussions (FGD) with instructional media experts and lecturers in the field of electrical engineering, especially regarding electrical motor control.
The results of the observation, questionnaire and FGD methods will be analyzed so that the criteria for a learning media about electrical motor control (EMC) are obtained; (2) Design: based on the criteria of learning media as a result of analysis (first step), then "design" is carried out through methods: (1) media 
selection; (2) format selection; and (3) initial design. The result of this second step is "draft EMC 1 Trainer"; (3) Development: a design product that embodies the "EMC 1 Draft Trainer" obtained in the second step, then developed through FGD. Based on the results of the FGD, the "EMC 1 Draft Trainer" was revised. Next "Draft EMC 1 Trainer" was validated by 3 validators (media experts) so that it became "EMC 2 Draft Trainer"; (4) Implementation: "EMC 2 Draft Trainer" obtained from the third step, then implemented in the field through trials in the Department of Electrical Engineering, Surabaya State University (check Figure 3). Based on the results of these trials, a revision of the deficiencies is still present in the "EMC 2 Trainer Draft", so that it becomes the final product in the form of "EMC Trainer".

The feasibility level of the EMC Trainer is determined by the criteria found in Table 1 below.

Table 1. Category of Feasibility Based on Rating Scale.

\begin{tabular}{ccc}
\hline No. & Rating scale (\%) & Feasibility Category \\
\hline 1 & $0 \%-25 \%$ & inappropriate \\
2 & $>25 \%-50 \%$ & unworthy \\
3 & $>50 \%-75 \%$ & decent \\
4 & $>75 \%-100 \%$ & very decent \\
\hline
\end{tabular}

(Source: Sugiyono, 2011)

\section{RESULT AND DISCUSSION}

\section{Results}

Validation results on "Draft EMC 2 Trainer" through 3 (three) instructional media experts, as shown in Table 2 below.

Table 2. Results of validation of Electrical Motor Control (EMC) Trainer by three media experts (validators)

\begin{tabular}{llcccc}
\hline No. & Description & Score $\mathbf{V}_{\mathbf{1}}$ & Score $_{\mathbf{2}}$ & SCore $_{\mathbf{3}}$ & Average Score \\
\hline 1 & Content Validity EMC Trainer & 91 & 93 & 95 & 93 \\
2 & Face Display EMC Trainer & 94 & 90 & 90 & 91,33 \\
3 & The Mobility Trainer EMC & 95 & 90 & 95 & 93,33 \\
4 & The Practicality EMC Trainer & 95 & 95 & 95 & 95 \\
5 & Appropriateness EMC Trainer & 95 & 93 & 95 & 94.33 \\
\hline
\end{tabular}

Description: $\mathrm{V}_{1}=$ Validator $1 ; \mathrm{V}_{2}=$ Validator 2 , dan $\mathrm{V}_{3}=$ Validator 3 


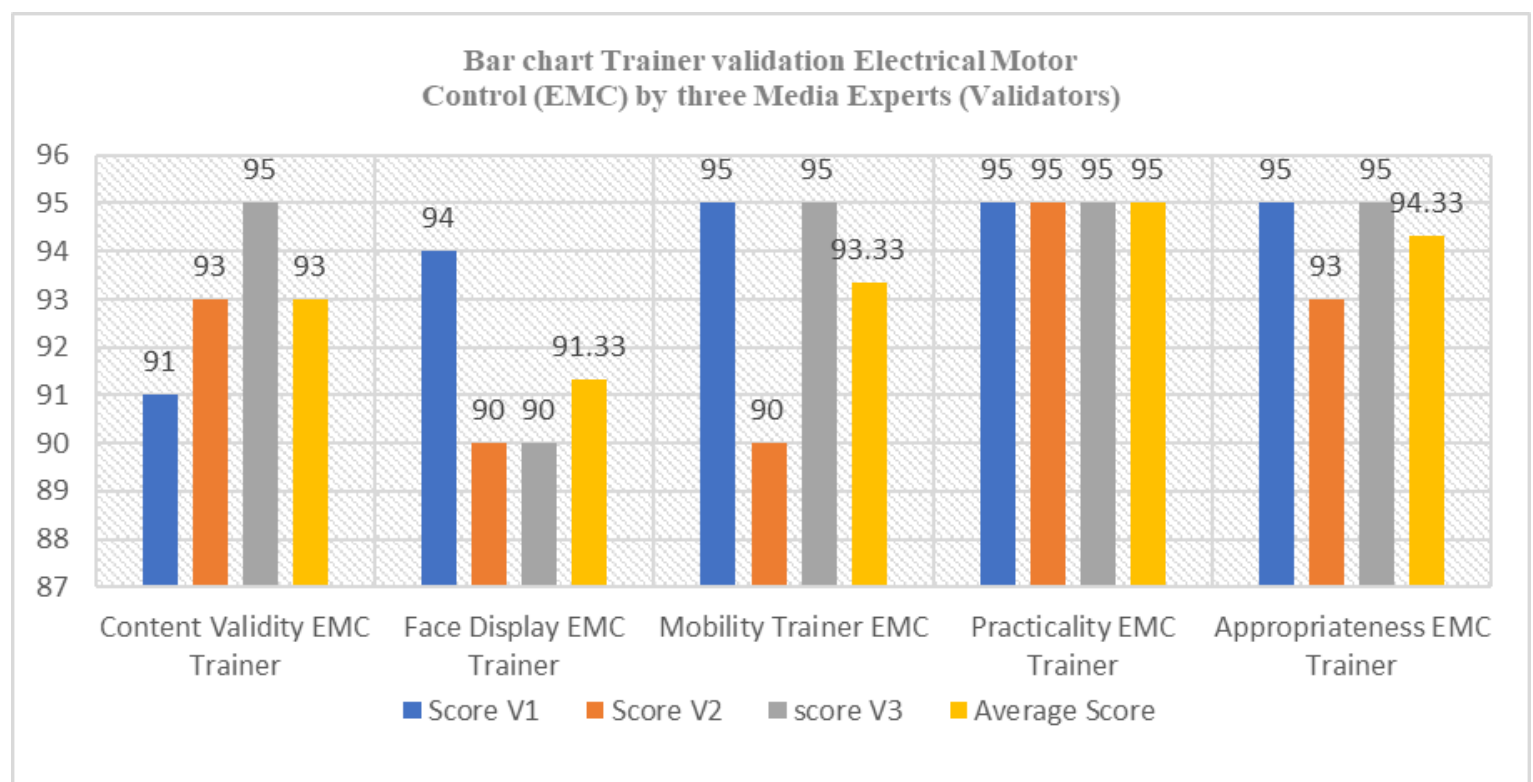

Figure 4. Bar chart Trainer validation Electrical Motor Control (EMC) by three Media Experts (Validators)

While the assessment of 35 students towards the EMC Trainer as shown in Table 2, and the bar chart of student assessment of the EMC Trainer as shown in Figure 5. As shown in Table 2, that from the aspect of the contents of the EMC Trainer, obtained an average score of 93 with the very decent category, while from the appearance aspect of the EMC Trainer, obtained a score of 91.33 (including the very decent category). Whereas from the aspect of

mobility, practicality, and feasibility of the EMC Trainer, each score was 93.33, 95.00 and 94.50, all of which included the "very decent" category. Based on the validator's assessment, it can be concluded, that the EMC Trainer is very suitable to be used in the learning process in the "Electric Power Installation" course in the Department of Electrical Engineering, Surabaya State University.

Table 3. Student Assessment of Feasibility of EMC Trainers

\begin{tabular}{|c|c|c|c|c|}
\hline No. & Description & Very Decent & Decent & Unworthy \\
\hline 1 & $\begin{array}{l}\text { Content Validity of EMC } \\
\text { Trainer }\end{array}$ & 18 & 17 & 0 \\
\hline 2 & Face Display EMC Trainer & 21 & 14 & 0 \\
\hline 3 & The Mobility of Trainer EMC & 23 & 12 & 0 \\
\hline 4 & The Practicality of EMC Trainer & 22 & 13 & 0 \\
\hline 5 & Feasibility of EMC Trainer & 25 & 10 & 0 \\
\hline
\end{tabular}

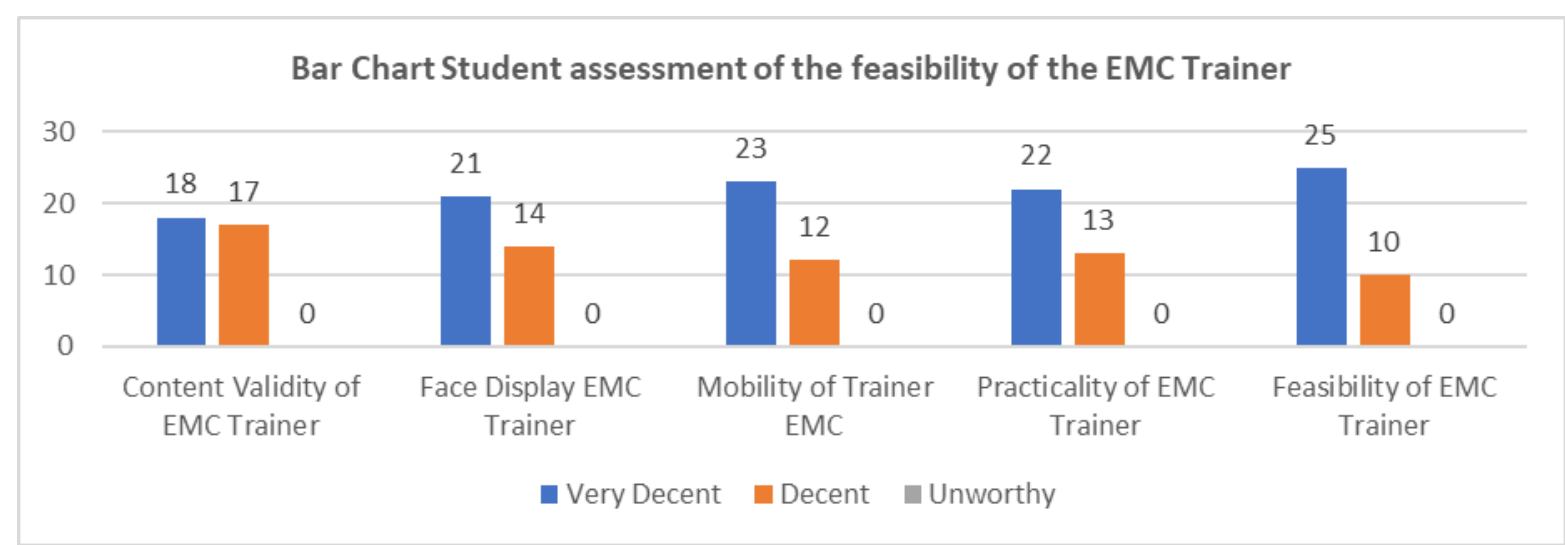

Figure 5. Bar Chart Student assessment of the feasibility of the EMC Trainer 
Based on Table 2, the student assessment of the EMC Trainer can be stated as follows: (1) A total of $18(51.43 \%)$ students stated that from the aspect of content, the EMC Trainer was very feasible, and the remaining 17 (49.57\%) students said they were fit for use in learning; (2) As many as $21(61.00 \%)$ students stated that the appearance of the EMC Trainer was very feasible, and the remaining 14 $(40.00 \%)$ students stated that they were fit to be used in learning ; (3) A total of $23(65.71 \%)$ students stated that the EMC Trainer mobility was very high feasible, and the remaining 12 (34.29\%) students stated that they were fit for use in learning; (4) As many as $22(62.85 \%)$ students stated that the practicality of the EMC
Trainer was very feasible, and the remaining $13(37.15 \%)$ students stated that they were fit for use in learning; (5) As many as 25 (71.42\%) students stated that the EMC Trainer is very suitable to be used in learning, while the remaining 10 (28.58\%) students stated that it was appropriate to be used in learning.

Based on the data in Table 3 above, in general, it can be stated that the EMC Trainer is very feasible to use in the course of learning Electrical Power Installation in the Department of Electrical Engineering, Surabaya State University.

Furthermore, student learning outcomes as shown in Table 4 and bar charts of student learning outcomes as shown in Figure 5.

Table 4. Student Learning Outcomes in the Electrical Power Installation Course

\begin{tabular}{cccc} 
No. & Total of Student & $\begin{array}{c}\text { The Range of Learning } \\
\text { Outcomes Scores }\end{array}$ & $\begin{array}{c}\text { Learning Outcomes } \\
\text { Category }\end{array}$ \\
\hline 1 & 3 & $50-60$ & less \\
2 & 6 & $61-70$ & enough \\
3 & 19 & $71-85$ & good \\
4 & 7 & $86-100$ & very good \\
\hline
\end{tabular}

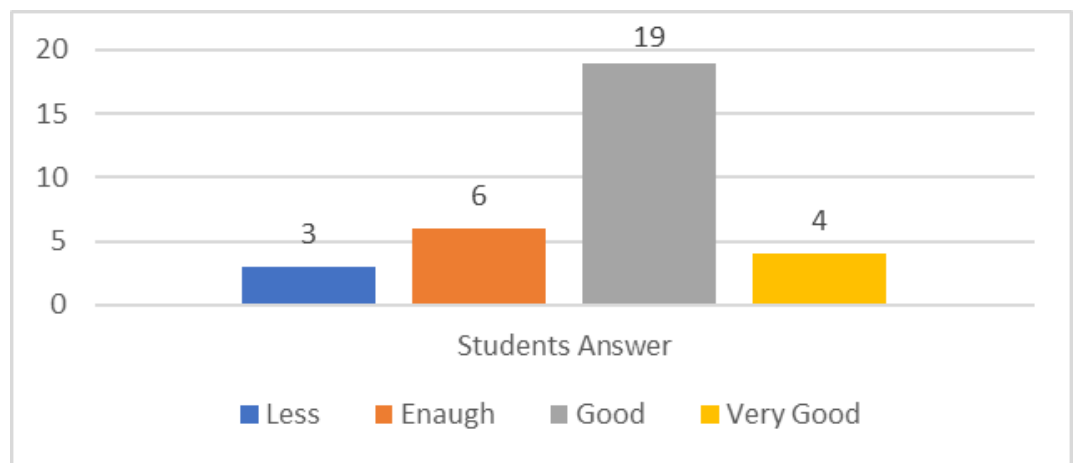

Figure 5. Student Learning Outcomes in the Electrical Power Installation Course

Based on Table 4 above, it can be explained that as many as $3(8.57 \%)$ students get scores in the range 50-60 with fewer categories, as many as $6(17.14 \%)$ students score in the range $61-70$ with sufficient categories, $19(54.28 \%)$ students get scores in the range 71-85 with good categories, and the remaining 7 (20\%) students score in the range 86-100, with excellent categories. Based on these data it can be stated that as many as $26(74.28 \%)$ students obtain learning outcomes scores in the 71-100 range, with good and excellent categories. Thus it can be concluded that the EMC Trainer is very effective as a learning medium in the subject of
Electric Power Installation in the Department of Electrical Engineering, Surabaya State University.

\section{Discussion}

This study found that: (1) based on the validator's assessment, that the EMC Trainer that had been developed was very feasible to be used in learning in the Electrical Power Installation course; (2) based on the assessment of students, that the EMC Trainer is very suitable to be used in learning courses in Electrical Power Installation in the Department of Electrical Engineering, Surabaya State 
University; and (3) as many as 26 (74.28\%) students get scores on learning outcomes in the 71-100 range, with good and excellent categories.

The findings of this study are in line with the results of research conducted by Eliza, Myori, and Wireksi (2017) in their research entitled "Electronic control system trainers for learning to operate electronic control systems" which found that: (1) validation conducted on media trainers scored 0.91 with a very high; and (2) the trainer's effectiveness test states that as many as $89.3 \%$ of students achieve the minimum completeness criteria. The results of this study are also in line with the findings of Widiantama (2017) through his research entitled "the development of DC motor speed control system trainers as a learning media for robotics practice" which concluded that: (1) media expert assessment of trainers scored 72 with a decent category; and (2) as many as $50 \%$ of students stated that trainers were worthy of being used in learning, and the remaining $50 \%$ of students stated that trainers were very feasible to use for learning.

The findings of this study support the results of research by Muslim, Achmad, Budi, and Aribowo (2018) written in his research journal entitled "development of human mechanic interface auotonics S070 trainer for electric motor installation learning" which concluded that: (1) validation of media content by learning media experts, get "very decent category" with a percentage of $89.58 \%$; and (2) with a learning media trial of 30 students in Surabaya Navy 1 Special Vocational School, getting "very decent category" with a percentage of $83.04 \%$.

As stated above, the EMC Trainer is declared effective for improving student learning outcomes in the Power Electric Installation course. Thus the results of this study are in line with the findings of Syarief and Isdianto (2015) through his research entitled "props for analyzing electromagnetic control interference on subjects operating electromagnetic control systems in class IX of SMK 3 Semarang" which concluded that there were significant differences between results student learning in the experimental class and control class ( $\mathrm{t}$ count of 2.72 is greater than $\mathrm{t}$ table of 2.00). The results of this study also support the results of Wirawan and Wahyudi's research (2016) with the title "development of electromagnetic trainer displays as learning media for basic electric concepts" which found that in the control class there was an increase in learning outcomes scores from 56.69 to 72.3, and in the experimental class increase from 56.11 to 77.44 .

\section{CONCLUSIONS AND SUGGESTIONS}

The study found that: (1) based on the validator's assessment, that the EMC Trainer that had been developed was very feasible to use in learning; (2) based on the assessment of students, that the EMC Trainer is very suitable to be used in learning courses in Electrical Power Installation in the Department of Electrical Engineering, Surabaya State University; and (3) EMC trainers are very effective, as many as $26(74.28 \%)$ students have obtained learning outcomes scores in the 71-100 range, with good and excellent categories.

Research suggests that learning for other subjects that have more or less the same characteristics as the "Electric Power Installation" course needs to be developed in the learning media so that student learning outcomes will be increase.

\section{ACKNOWLEDGMENT}

This research can be done with the help of various parties. For this valuable opportunity, he expressed his gratitude to the Chairperson and secretary of the Department of Electrical Engineering, Surabaya State University, who gave the opportunity where this research could be carried out smoothly in accordance with the planned time schedule. Likewise, to students who have been actively involved in this research, so that the necessary research data is obtained in full, many thanks are conveyed.

\section{REFERENCES}

Akhtar, A.N., \& Ali, R.A. (2012). Use of media for effective its importance: Some consideration. Journal of Elementary Education, 18 (1-2), 35-40.

Borg, W.R. \& Gall, M.D. (2003). Educational research an introduction. New York: Longman.

Han I. \& Shin's W.S. (2016). The use of mobile learning management system and an academic achievement of online 
student. Computers \& Education. DOI: 10.1016/j. compude.2016.07.003.

Instruksi Presiden Republik Indonesia (Inpres) Nomor 9 Tahun 2016 Tentang Revitalisasi Pendidikan Vokasi.

Kemeterian Pendidikan dan Kebudayaan Republik Indonesia. (2016). Naskah Revitalisasi Pendidikan Vokasi. Jakarta: Kemendikbud.

Muslim, S., Achmad, F., Budi. K.S., dan Aribowo, W. (2018) pada jurnal penelitiannya yang berjudul "development of human mechanic interface auotonics S070 trainer for electric motor installation learning". Published by Atlantis Press. Article under the CC BY-NC license (http: //creativecommons.org/ licenses /bync/4.0/).

Naskah Revitalisasi Pendidikan Vokasi. (2016). Jakarta: Kemendikbud.

Preeti. (2014). Education and role of media in education system. International Journal of Scientific Engineering and Research, Volume 2, Issue 3, March, 2014, 174-177.

Omadara, O.D., \& Adu, E.I. (2014). Relevance of educational media and multimedia technology for effective service delivery in teaching and learning processes. IQSR Journal of Research \& Method in Education, Volume 4, Issue 2 Ver. 1 (Mar-Apr.2014), 48-51.

Eliza, F., Elvany D., Wireksi, G.F. (2017). sistem kendali elektronik. Jurnal $\begin{array}{lllll}\text { Edukasi } & \text { Elektro. } & \text { Vol } & 1 & \text { No.2 }\end{array}$ November 2017, p. 110-118 Universitas Negeri Yogyakarta.

Sarrab, M., Alzahrani, A., Alwan, N.A., \& Alfarraj, O. (2014). From traditional learning into mobile learning in education at university level: Undergraduate students perspective.
International Journal of Mobile learning and organization, 8(3-4), 167186. DOI:10.1504/IJMLO.2014. 06 7014.

Syarief, Ahmad, dan Isdianto. 2015). Aplikasi alat peraga, analisa gangguan pengendali elektromagnitik pada mata pelajaran mengoperasikan sistem pengendali elektromagnitik kelas IX SMKN 3 Semarang. Edu Elektrikal Vol 4 No.1, p. 58 Unversitas Negeri Semarang.

Sudira, P.-a. (2018). TVET Abad XXI: Filosofi, teori, konsep, dan strategi pembelajaran vokasional. Yogyakarta: UNY Press.

Sudira, P.-b. (2018). Metodologi pembelajaran vokasional abad XXI. Yogyakarta: UNY Press.

Sugiyono. (2011). Metode Penelitian Pendidikan (Pendekatan Kuantitatif, Kualitatif dan R\&D). Bandung: CV. Alfabeta.

Teodorescu, A. (2015). Mobile learning and its impact on buissines English learning. Procedia-Social and Behavioral Sciences180,1535-1540. DOI:10.1016 /j.sbspro.2015.02.303.

Undang-undang No. 20 Tahun 2003 pasal 1 ayat 1 tentang Sistem Pendidikan Nasional.

Wirawan, B.Y. dan Wahyudi. (2016). Pengembangan peraga trainer elektromagnetik sebagai media pembelajaran konsep kelistrikan dasar. Jurnal Pendidikan Teknik Mesin, Vol.16, No.1 Universitas Negeri Semarang.

Widiantama, O. (2015). Pengembangan trainer sistem kendali kecepatan motor dc sebagai media pembelajaran praktik robotika. Jurnal Pendidikan Teknik Mekatronika Vol. 7 No.2 Maret 2017, p.7 Universitas Negeri Yogyakarta. 